pag

Business School

WORKING PAPER SERIES

Working Paper

2015-623
Modeling the causal linkages between nuclear energy, renewable energy and economic growth in developed and developing countries

Anis Omri

Nejah ben mabrouk

Amel Sassi-Tmar

http://www.ipag.fr/fr/accueil/la-recherche/publications-WP.html

IPAG Business School

184, Boulevard Saint-Germain

75006 Paris

France 


\title{
Modeling the causal linkages between nuclear energy, renewable energy and economic growth in developed and developing countries
}

\author{
Anis Omri* \\ Higher Institute of Industrial Management, University of Sfax, Tunisia \\ Nejah ben mabrouk \\ Faculty of Economics and Management of Mahdia, University of Monastir, Tunisia \\ Amel Sassi-Tmar \\ National Engineering School of Tunis, University of Elmanar, Tunisia
}

\begin{abstract}
This paper investigates the causal relationship among energy consumption (i.e., nuclear energy and renewable energy) and economic growth using dynamic simultaneous-equation panel data models for 17 developed and developing countries ; namely, Argentina, Belgium, Brazil, Bulgaria, Canada, Finland, France, Hungary, India, Japan, Netherlands, Pakistan, Spain, Sweden, Switzerland, the United Kingdom, and the United States ; over the period 1990-2011. Our empirical results indicate that there is a unidirectional causality running from nuclear consumption to economic growth in Belgium and Spain, while there is a unidirectional causality running from economic growth to nuclear consumption is supported in Bulgaria, Canada, Netherlands, and Sweden. A bidirectional relationship appears in Argentina, Brazil, France, Pakistan, and the USA, while no cousality exists in Finland, Hungary, India Japan, Switzerland, and the U.K. Second, the results for the second nexus among renewable energy and economic growth show that there is unidirectional causality running from renewable consumption to economic growth in Hungary, India, Japan, Netherlands, and Sweden, while there exist a unidirectional running from economic growth to renewable consumption in Argentina, Spain, and Switzerland. A bidirectional relationship is supported in Belgium, Bulgaria, Canada, France, Pakistan, and the USA, while no causality exists in Brazil, Finland, and Switzerland. Third, we find the existence of a bidirectional causality between nuclear consumption and economic ; and a unidirectional causality running from economic growth to renewable energy consumption for the panel of countries.
\end{abstract}

Keywords : Nuclear energy, Renewable energy, Economic growth, Simultaneous-equation models. 
* Corresponding author. Tel.: +216 97914294.

E-mail address: omrianis.fsegs@gmail.com (A. Omri).

\section{Introduction}

The issue of causality among energy and economic growth has been an interesting topic concerning energy economists' for the last few years. Early models such as that of Solow [1], did not explain how improvements in technology come about, so this model assumes that technological change is exogenous and not introduce resources or energy. However, there some economists believe that energy plays a pivot role in economic growth as well as being a crucial factor in explaining the industrial revolution [2, 3]. As well, some others such as Hall et al. [4] support that either increase in energy consumption accounts for most apparent productivity growth, or that innovation in technological change mainly increases productivity by allowing more energy consumption. Therefore, energy use has considered as a potential source of economic growth, which has triggered interest in empirically identifying the nature of causal linkages between energy consumption and economic growth in either existence or lack of causality. So, identifiying the direction of causality between energy consumption and economic growth provides important inferences in establishing sound energy policies.

The empirical literature on the causal relationship between energy consumption and economic growth could be synthesized into four testable hypothesis: feedback, growth, consevation, and neutrality hypothesis [5, 6]. According to the feedback hypothesis, there is a bi-directional causal relationship between energy consumption and economic growth. It implies that energy consumption and economic growth are interrelated and may very well serve as complements to each other [5]. The growth hypothesis suggests that there is unidirectional causal relationship raunning from energy consumption to economic growth. It implies that energy consumption plays an important role in economic growth both directly and indirectly in the production process as a complement to labor and capital. The conservation hypothesis postulates unidirectional causality running from economic growth to energy consumption, implying that energy conservation policies do not adversely impact economic growth. Finally, the neutrality hypothesis suggests that the no causality between energy consumption and economic growth. This hypothesis considers energy consumption to be a small component of overall output and thus have little or no impact on real GDP. It implies that neither conservative nor expansive policies in relation to energy consumption have any effect on economic growth.

The reason which conducts researchers to focus on the link between energy resources and economic growth, is the vision of sustainable development. The fact that many countries agreed on conserving energy and reducing $\mathrm{CO}_{2}$ emissions has increased the attractiveness of energy consumption related studies. However, the key dynamic in those studies is the consumption of renewable and nuclear energy. With the growing importance of sustainable development, researchers have interested more in the impacts of nuclear and renewable consumption on economic growth.

In light of the aforementioned hypotheses, the task of this study is to examine both causality direction between "nuclear energy consumption and economic growth" and " renewable energy consumption and economic growth", we herewith concentrate on reviewing the empirical studies in this regard and summarize the existing literature in Table 1. 
The first nexus is closely related to the causal relationship between nuclear energy consumption and economic growth. This nexus suggests that economic growth and energy consumption may be jointly determined, because higher growth in real GDP requires more nuclear consumption. Likewise, a growth in real GDP is responsible for a high level of nuclear energy consumption. According to this first nexus, only a few empirical studies have focused on the two-way causation between nuclear consumption and economic growth. In an early study Yoo and Jung [7] analyzed the causality direction between nuclear energy consumption and economic growth for Korea. The results show evidence of the growth hypothesis. The single-country time series literature was extended by Menyah and WoldeRufael [8] who supported the neutrality hypothesis for the USA. This result was substantiated by the study of Payne and Taylor [9]. Another single-country study was carried out by WoldeRufael [10] for India using real gross fixed capital formation as the control variable. In line with Yoo and Jung [7], the evidence on the growth hypothesis was supported.

In addition to the single-country time series studies, some of the recent studies carried out multi-country time series analysis to provide cross-country evidence. In an examination of the two-way linkages between nuclear energy consumption and economic growth for a sample of six countries, Yoo and Ku [11] supported the growth hypothesis for Korea; conservation hypothesis for France and Pakistan; feedback hypothesis for Switzerland; and neutrality hypothesis for Argentina and Germany. Wolde-Rufael and Menyah [12] analyzed the direction of causality between nuclear energy consumption and economic growth in nine industrialized countries. They indicated the existence of the growth hypothesis for Japan, Netherlands, and Switzerland; conservation hypothesis for Canada and Sweden; and feedback hypothesis for France, Spain, the UK, and the USA. By employing the same method, Lee and Chiu [13] considered six highly industrialized countries. In contrast to Wolde-Rufael and Menyah [12], they supported the feedback hypothesis for Canada, Germany, and United Kingdom (UK); neutrality hypothesis for France and the USA; and conservation hypothesis for Japan. Chu and Chang [14] used the same methodology and their findings supported the growth hypothesis for Japan, U.K., and the USA; and neutrality hypothesis for Canada France, and Germany.

Apart from the time series studies, a few number of studies used panel data methodology. Apergis et al. [15] employed a panel dataset of 19 developed and developing countries by estimating panel VECM, and have found evidence of feedback hypothesis between nuclear energy consumption and economic growth in the short run. While they proved the validity of the growth hypthesis in the long run. By using the same methodology for a panel of sixteen developed and newly developing countries, Apergis and Payne [16] supported the feedback hypothesis in the short-run and the growth hypothesis in the long-run. Another study carried out by Nazlioglu et al. [17] for 14 OECD countries, and have supported the feedback hypothesis.

According to the second nexus, several studies in the literature have examined the relationship between renewable energy consumption and economic growth. The results of these studies have no consensus because of using different data, period, and methodological approach. Therefore, some studies have found unidirectional causality running from renewable energy consumption to economic growth, and running from economic growth to renewable energy consumption. On the other hand, others have found no causality and/or 
bidirectional causality between renewable energy consumption and economic growth [15, 1825]. USA over the period of 1969-2009, and they they supported the conservation hypothesis. In the same context, Payne [19] used Toda-Yamamoto causality tests to analyze the relationship between renewable and non-renewable energy consumption and economic growth for the period of 1949-2006, and the results supported the neutrality hypothesis. For the USA, Payne [22] examined the causal relationship between biomass energy consumption and real GDP by using the Toda-Yamamoto causality tests for Granger causality within a multivariate framework for the period of 1949-2007. The empirical findings supported the growth hypothesis.

In addition to the single country time series studies, some of the recent studies carried out multi-country time series analysis to provide cross-country evidence. Apergis and Payne [20] used a data of six Central American countries to examine the causal relationship between renewable energy consumption and economic growth for the period of 1980-2006. In the short and the long-run, the results suggest feedback hypothesis. The results for Brazil, China, India, Indonesia, Philippines, and Turkey by Salim and Rafiq [24] suggested the existence of conservation hypothesis.

Apart from the time series studies, some of recent studies used panel data methodology. For the period of 1994-2003 in 18 emerging countries, Sadorsky [26] used panel error correction model to test the relationship between economic growth and renewable energy consumption, and the results support conservation hypothesis. Apergis and Payne [27] examined the causal relationship between renewable energy consumption and economic growth in 13 Eurasia countries for the period of 1992-2007 in both the short-run and longrun, by using Granger causality tests.Empirical result ssupported the feedback hypothesis. For 27 European countries, Menegaki [21] used multivariate panel framework random effect model for the period of 1997-2007. Empirical results showed the existence of the neutrality hypothesis.

The aim of this study is to examine both causality direction between "nuclear consumption and economic growth" and " renewable consumption and economic growth" by using a dynamic simultaneous-equation models (DSEMs). Compared to previeous studies (Table 1), we use a dynamic simultaneous-equation modeling approach to investigate the twoway causation between "nuclear consumption and economic growth" and "renewable consumption and economic growth". In the literature, there is no study which has investigated this relationship using (DSEMs).This modeling approach relies on the GMMestimator and allows us to examine simultaneously the following combined causality effects: i) from nuclear energy consumption (renewable energy consumption) to economic growth; and ii) from economic growth to nuclear energy consumption (renewable energy consumption).

The plan of this study is organized as follows: after introduction which is presented in Section 1 above, Section 2 shows the econometric methods and data source, Section 3 presents empirical results and final Section concludes the study and offers some policy implications. 


\section{Econometric Method and Data}

\subsection{Econometric method}

The objective of this paper is to use a production function approach to explain the interrelationship between two types of energy consumption (nuclear energy and renewable energy) and economic growth where GDP depends on nuclear (renewable) energy consumption and others inputs. The extended Cobb-Douglas production framework helps us to explore the two-way linkages between the two energy variables and economic growth. These variables are in fact endogenous. It is therefore worth investigating the interrelationships between these variables by considering them simultaneously in a modeling framework.

For this purpose, we employ the Cobb-Douglas production function including capital and labor as additional factors of production. Apergis and Payne [16, 27], Wolde-Rufael and Menyah [12], and Marques and Fuinhas [32], among others, include the two energy variables in their empirical model to examine their impacts on economic growth. While they find generally that nuclear energy consumption and renewable energy consumption stimulate economic growth. To investigate the interrelationship between energy and economic growth in 17 developed and developing countries, the following augmented Cobb-Douglas production function is employed:

$$
\mathrm{Y}=\mathrm{AK}^{\alpha_{1}} E^{\alpha_{2}} \mathrm{~L}^{\alpha_{3}} e^{\mu}
$$

By taking log, the linearized Cobb-Douglas production function is:

$$
\ln Y_{t}=\alpha_{0}+\alpha_{1} \ln E_{t}+\alpha_{2} \ln K_{t}+\alpha_{3} \ln L_{t}+\mu_{t}
$$

Since our study is a panel data study, Eqs. (2) can be written in panel data form as follows:

$$
\ln Y_{i t}=\alpha_{0}+\alpha_{1 i} \ln E_{i t}+\alpha_{2 i} \ln K_{i t}+\alpha_{3 i} \ln L_{i t}+\mu_{i t}
$$

Where $\alpha_{0}=\ln \left(\mathrm{A}_{0}\right)$, the subscript $\mathrm{i}=1, \ldots . ., \mathrm{N}$ denotes the country (in our study, we have 17 countries) and $\mathrm{t}=1, \ldots \ldots ., \mathrm{T}$ denotes the time period (our time frame is 1990-2011), $Y$ is real domestic output, $E$ is the indicator of energy consumption (i.e., nuclear or renewable), $K$ is capital, and $L$ is labor. The term A refers to technology and e the error term. The output 
elasticity with respect to energy consumption, capital and labor is $\alpha 1, \alpha 2$ and $\alpha 3$ respectively. When Cobb-Douglas technology is restricted to $(\alpha 1+\alpha 2+\alpha 3=1)$ we get constant returns to scale. We have converted all the series into logarithms to linearize the form of the nonlinear Cobb-Douglas production. It should be noted that simple linear specification does not seem to provide consistent results. Therefore, to cover this problem, we use the log-linear specification to investigate the two-way linkages energy consumption (nuclear or renewable) and economic growth in 17 developed and developing countries.

We then use the production function in Eqs. (3) to derive the empirical models to simultaneously examine the interactions between energy consumption (i.e., nuclear or renewable) and economic growth.

$$
\begin{aligned}
& \ln Y_{i t}=\alpha_{0}+\alpha_{1 i} \ln E_{i t}+\alpha_{2 i} \ln K_{i t}+\alpha_{3 i} \ln L_{i t}+\mu_{i t} \\
& \ln E_{i t}=\alpha_{0}+\alpha_{1 i} \ln Y_{i t}+\alpha_{2 i} \ln C O_{2 i t}+\alpha_{3 i} \ln O C_{i t}+\alpha_{4 i} \ln O P_{i t}+\mu_{i t}
\end{aligned}
$$

In the above equations, Eqs. (4) states that nuclear energy consumption, renewable energy consumption, capital stock $(\mathrm{K})$ and labor force $(\mathrm{L})$ are the driving forces of economic growth [12, 23, 33-35]. Nuclear and renewable energy consumption were introduced as inputs in the production process. Analyzing the impact of different sources of energy supply helps to design sectoral energy and environmental strategies and policies. Nuclear and renewable energy consumption play an important role not only in meeting the energy needs of many countries, but also in mitigating emissions. However, the European Union [36] argues that Europe would not have been able to make any significant impact on reducing $\mathrm{CO}_{2}$ emissions without the use of nuclear and renewable energy. They offer significant opportunities for further growth that can facilitate the transition to a global sustainable energy supply by the middle of this century [37]. The GFCF is included to proxy capital stock in this study. Capital is normally disaggregated into public capital and human capital. Public capital is mainly provided by government, which includes telecommunication, electricity, and water for public usage. The GFCF is part of public capital, which impacts economic growth as it is normally assumed that public capital appears to be a crucial component of the production function. Capital stock enters the production function directly. It influences the multifactor productivity and thereby production in an indirect way. On the other hand, human capital mainly deals with the skills and qualifications of people, which are acquired through explicit training and on the job experience. A higher level of capital stock, thus, reflects greater productivity and efficiency, which is positively related to economic growth. Moreover, traditionally in Cobb- 
Douglas production function, labor is expected to affect positively the economic growth. Labor, together with capital, is considered to be a key input in the production process.

Eqs. (5) postulates that nuclear and renewable energy consumption can be influenced by economic growth, environmental degradation $\left(\mathrm{CO}_{2}\right)$, Oil consumption (OC), and real oil price (OP). Likewise Sadorsky [26] and Lee and Chui [13], the variables to be included in this equation are selected in accordance with economic theory and data availability. Real GDP is included in the model to measure economic growth. Higher economic growth should lead to higher energy consumption (nuclear or renewable) and thus there should have positive association between these two. In accordance with societal concern over greenhouse effects, the variable of $\mathrm{CO}_{2}$ emissions is included in the Eq.5 as an important additional explanatory variable. Higher $\mathrm{CO}_{2}$ emissions create demand for cleaner environment and encourages usage of alternative nuclear and renewable energy that is free from this evil effect. So a positive relation between nuclear and renewable energy consumption and $\mathrm{CO}_{2}$ emissions is expected. Oil price and Oil consumption are also included in the Eq.5. Higher oil price increase the demand for nuclear and renewable energy, implying a positive relationship between the demand for nuclear and renewable energy and oil price. In contrast, higher oil consumption decrease the demand for nuclear and renewable energy, implying a negative relationship between the demande for nuclear and renewable energy and oil consumption [28].

\subsection{Estimation technique}

At the empirical level, we allow our dynamic simultaneous-equation models in Eqs. (4) and

(5) to have a dynamic panel specification where the one-period lagged levels of the dependent variables (i.e., real GDP, nuclear energy consumption, and renewable energy consumption) can affect their current levels. Our dynamic models with panel data are then simultaneously estimated by using the Generalized Method of Moments (GMM) estimator. This approach uses a set of instrumental variables to solve the endogeneity problem of the regressors. Our proposed modeling is as follows:

$$
\begin{aligned}
& \ln Y_{i t}=\alpha_{0} \ln Y_{i t-1}+\psi \ln E_{i t}+\sum_{j=1}^{2} \beta_{j} \text { controls }_{i t}+\mu_{i t} \\
& \ln E_{i t}=\alpha_{0} \ln E_{i t-1}+\phi \ln Y_{i t}+\sum_{j=1}^{3} \beta_{j} \text { controls }_{i, t}+\mu_{i t}
\end{aligned}
$$


$\mathrm{i}=1, \ldots \ldots \ldots . ., \mathrm{N} ; \mathrm{t}=1, \ldots \ldots \ldots \ldots, \mathrm{T}$.

were the subscript $\mathrm{i}=1, \ldots ., \mathrm{N}$ denotes the country and $\mathrm{t}=1, \ldots \ldots, \mathrm{T}$ denotes the time period; $\ln Y_{i t-1}$ and $\ln E_{i t-1}$ represent, respectively, the log of lagged dependant variables of economic growth $\left(\ln Y_{i t}\right)$ and the energy type variables $\left(\ln E_{i t}\right) ; \alpha_{0}$ is the parameter to be estimated; controls represents the vector of core control variables we detailed in Eqs (4) and (5) ; $\psi$ captures the effect of energy type variables on economic growth ; $\phi$ captures the effect of economic growth on each energy type variables; and $\mu$ is the error term.

\subsection{Data specifications}

The annual data used in this study cover the period from 1990 to 2011 for seventeen developed and developing countries ; namely, Argentina, Belgium, Brazil, Bulgaria, Canada, Finland, France, Hungary, India, Japan, Netherlands, Pakistan, Spain, Sweden, Switzerland, the United Kingdom, and the United States. The variables in this study include real GDP (Y) in billions of constant 2005 US \$, nuclear energy consumption (NEC) is expressed in terms of Terawatt-hours (TWh), renewable energy consumption (REC) is mesured by combustible renewables and waste \% of total energy defined in thousands of metric tons, gross fixed capital formation (K) in billions of constant 2005 US \$, total labor force (L) in million, $\mathrm{CO}_{2}$ emissions in million tonnes carbon dioxide, real oil price (OP) is mesured using the spot price on West Texas Intermediate (WTI) crude oil, and oil consumption (OC) in thousand barrels daily. Nuclear energy consumption, $\mathrm{CO}_{2}$ emissions, oil price, and oil consumption are obtained from the British Petroleum Statistical Review of World Energy (BP [38]). Real GDP, combustible renewables and waste \% of total energy, gross fixed capital formation, and total labor force are obtained from the Word Bank’s World Development Indicators.

The mean value, the standard deviation, and the coefficient of variation of different variables for individual's countries and also for the panel are given below in Table 2. This table provides a statistical summary associated with the actual values of the used variables for each country. The highest means of real GDP (10861.61) and nuclear consumption (759.357) are in the United States, while the highest mean of the variable related to the renewable consumption (150841.8) is in India. The lowest means of real GDP (25.565) and renewable consumption (508.290) are in Bulgaria. Additionally, India is the highest volatility country (defined by the standard deviation) in real GDP (0.430), followed by Belgium (0.331), and Pakistan (0.270). It is also noted that Pakistan is more volatile in nuclear energy consumption; 
its coefficient of variation is 0.758 , which is the highest when compared to other countries coefficient of variation. Also, we can see that the United Kingdom is more volatile in renewable energy; its coefficient of variation is 0.620 , which is the highest when compared to other countries coefficient of variation.

\section{[Please Insert Table 2]}

\section{Results and Discussions}

The above simultaneous equations ( 6 and 7 ) are estimated by making use of two-stage least squares (2SLS), three stage least squares (3SLS), and the generalized method of moments (GMM). What follows, we only report the results of GMM estimation. While the parameter estimates remained similar in magnitude and sign, the GMM results are generally found to be statistically more robust.

While estimating the two-way linkages between nuclear (renewable) energy consumption and economic growth, $\mathrm{K}, \mathrm{L}, \mathrm{CO}_{2}, \mathrm{OP}$, and $\mathrm{OC}$ are used as instrumental variables. The Durbin-Wu-Hausman test was used to test for endogeneity. The null hypothesis of the DWH endogeneity test is that an ordinary least squares (OLS) estimator of the same equation would yield consistent estimates: that is, an endogeneity among the regressors would not have deleterious effects on OLS estimates. A rejection of the null indicates that endogenous regressors' effects on the estimates are meaningful, and instrumental variables techniques are required. In addition, the validity of the instruments is tested using Hansen test which cannot reject the null hypothesis of overidentifying restrictions. That is, the null hypothesis that the instruments are appropriate cannot be rejected. In the same order, we performed the augmented Dickey and Fuller [39] and Philips and Perron [40] unit-root tests on the used variables. We find that all the series are stationary in level. Based on the diagnostic tests, the estimated coefficients of Eqs. (6) and (7) are given in Tables 3 and 4.

Beginning with Table 3, both models 1 and 2 consider the determinants of real GDP measured in billions of constant 2005 US \$. The only difference between these two models is the use of two different energy proxies. In model 1, we included nuclear energy and in model 2, we included renewable energy as proxy for energy consumption.

In model 1, we find that nuclear energy consumption has a positive and significant impact on real GDP for Belgium, Finland, Hungary, India, Japan, Spain, Switzerlands, and the U.K. This implies economic growth is elastic with respect to nuclear energy consumption, 
and a $1 \%$ rise in nuclear consumption raises economic growth within a range of $0.173 \%$ (Finland) to $0.429 \%$ (U.K.). This result is consistent with the findings of Wolde-Rufael [10] and Wolde-Rufael and Menyah [12]. For the remaining countries, no significant relationship is found. The coefficient of capital is significant for 13 countries out of 17 . Only for Argentina, Bulgaria, Finland, France, Hungary, Netherlands, Pakistan, Spain, Sweden, Switzerlands, U.K., and USA, it positively affects real GDP, however for Brazil and India it has a significant negative impact. For the remaining countries, no significant relationship is found. The coefficient of labor is significant for all the countries except for Bulgaria, Canada, India, Japan, Sweden, Switzerlands. For the panel results, we find that the effect of nuclear energy consumption on economic growth is statistically significant at the $5 \%$ level. The magnitude of 0.177 implies that a $1 \%$ increase in nuclear energy consumption increases the real income of the selected countries by around $0.18 \%$. The results are consistent with the findings of Apergis and Payne [16, 27], Wolde-Rufael and Menyah [12], and Lee and Chui [28]. Capital stock has a positive and statistically significant effect on real GDP, while the impact of inflation is found to be negative and statistically significant. Regarding the model 2, we find that renewable energy consumption has a positive and significant effect on real GDP only for Brazil, Finland, Hungary, India, Japan, Netherlands, Sweden, and the United Kingdom. This suggests that an increase in renewable energy consumption tends to promote economic growth $[22,25]$. The coefficient of capital variable has a positive significant impact on energy consumption for 9 countries out of 17. It has a significant negative impact only for Brazil, while for the remaining countries, no significant relationship is found. This indicates an increase in real capital decrease renewable energy consumption in Brazil. Lobor force has a significant impact on economic growth for 9 countries out of 17. Only for Argentina, Canada, Finland, Hungary, Netherlands, the U.K., and the USA, it positively affects real GDP, however for Belgium, Brazil and Spain it has a significant negative impact. For the panel results, we find that only the capital stock has a positive significant impact on real GDP at $5 \%$ level.

\section{[Please Insert Table 3]}

The empirical results pertaining to Eqs. (7) are given in Table 4. In this table, we present the impact of real GDP, $\mathrm{CO}_{2}$ emissions, oil price, and oil consumption on nuclear consumption (model 1) and on renewable consumption (model 2). In model 1, we find that real GDP has a positive and significant impact on nuclear energy consumption for Bulgaria, Canada, Finland, Hungary, India, Japan, Netherlands, Sweden, Switzerlands, and the U.K. 
This implies that nuclear energy demand is elastic with respect to real GDP, and a 1\% rise in real GDP raises nuclear energy consumption within a range of $0.175 \%$ (Finland) to $0.369 \%$ (U.K.), perhaps because countries with higher income levels are more likely to have their basic needs and are concerned with environmental problems, as well as they have more money to invest in nuclear energy development. Thus, for highly industrialized countries, economic development leads to higher nuclear energy demand [13]. Regrading the pollutant variable, we find that $\mathrm{CO}_{2}$ emissions have a positive and significant impact on the demand of the nuclear energy for Brazil, Canada, Finland, India, Spain and Switzerland. This implies that higher $\mathrm{CO}_{2}$ emissions in these countries create demand for cleaner environment and encourages usage of alternative nuclear energy that is free from this evil effect. The impact of real oil price on the demand of nuclear energy is positive and significant for 9 countries out of 17. This implies that a $1 \%$ increase in real oil price raises the nuclear energy consumption by around 0.16\%, 0.18\%, 0.12\%, 0.19\%, 0.41\%, 0.19\%, 0.24\%, and 0.344\% for Belgium, Brazil, Bulgaria, Finland, France, Netherlands, Spain, and The U.K., respectively. Finally, oil consumption has a negative and significant impact on nuclear energy consumption for 7 countries out of 17 . This implies that a $1 \%$ increase in oil consumption decreases the demand of nuclear energy by around $0.17 \%, 19 \%, 13 \%, 24 \%, 15 \%, 20 \%$, and $29 \%$ for Argentina, Brazil, Hungary, Japan, Pakistan, Switzerland, and the USA, respectively. This indicates that a reduction in oil consumption will lead to an increase in nuclear energy demand. Thus, the above results imply that under the upsurge in international crude oil prices and oil supply shortages, countries can develop nuclear energy to replace their demands for oil. For the panel results, we find that the impact of real GDP on nuclear energy consumption is positive and significant at the $5 \%$ level. The magnitude of 0.278 implies that a $1 \%$ increase in economic growth increases the of nuclear energy demand by around $0.28 \%$, respectively. This result is consistent with findings of Apergis et al. [15] for nineteen developed and developing countries. Oil price has also a postive and significant impact on nuclear energy consumption at the $5 \%$ level, while the impact of oil consumption is found to be statistically insignificant. The magnitude of 0.179 implies that a $1 \%$ increase in oil price increases the demand of nuclear energy by around $0.18 \%$, and it has a substitute relationship between nuclear energy and oil in the panel case.This result could be in favor with Vaillancourt et al. [41], who note that the long-run energy and environmental strategies for growing global energy demands have taken up the transition from fossil fuels to renewable or other energy with nongreenhouse gas emissions (i.e. nuclear energy). Finally, the effect of oil consumption on nuclear energy demand is negative and statistically insignificant. 
In model 2, we find that the impact of real GDP on renewable energy consumption is positive and significant for Argentina, Brazil, Finland, Spain, Switzerland, and the U.K. This implies that renewable energy consumption is elastic with respect to real GDP, and a 1\% rise in real GDP raises renewable energy consumption within a range of $0.165 \%$ (Brazil) to 0.414\% (U.K.). $\mathrm{CO}_{2}$ emissions have also a positive and significant impact on renewable energy demand for 9 countries out of 17 . This implies that a $1 \%$ rise in $\mathrm{CO}_{2}$ emissions raises renewable energy consumption by around $0.16 \%, 0.17 \%, 0.21 \%, 0.19 \%, 0.28 \%, 0.22 \%$, 0.2\%, 0.27\%, 0.29\%, and 0.28\% for Argentina, Belgium, Brazil, Canada, France, Japan, Sweden, the U.K., and the USA, respectively. This result is consisting with the findings of Sadorsky [26] and Salim and Rafiq [24]. We also find that real oil price has a positive and significant impact on renewable energy demand only for 8 countries out of 17 . However, oil consumption has a negative and significant impact on nuclear energy consumption for 7 countries out of 17 . This indicates that a reduction in oil consumption will lead to an increase in nuclear energy demand in these countries. For the panel results, GDP elasticities are positive and statistically significant at the $5 \%$ level. The magnitude of 0.227 implies that a $1 \%$ increase in economic growth increases renewable energy demand by around $0.23 \%$. Salim and Rafiq [24] found similar results when analyzing these linkages for six major emerging economies. $\mathrm{CO}_{2}$ emissions and oil consumption are found to have an insignificant impact on renewable energy consumption. Finally, we find that real oil price seem to have least impact on renewable energy consumption. These results conform to Sadorsky's [26] findings. This exogeneity of oil price variable may be due to the fact that real oil prices were falling for much of the estimation period. Furthermore, another reason might be that for most of these countries oil prices have been subsidized to avoid any adverse effect on the economy.

\section{[Please Insert Table 4]}

Overall, the above-discussed results regarding the links between energy type variables and economic growth for individual cases show that there is a positive unidirectional causality running from nuclear energy consumption to economic growth in Belgium and Spain. This indicates that, in these countries, increases in nuclear energy consumption caused increases in economic growth implying that energy conservation policies that adversely impact on nuclear energy consumption may have an adverse effect on economic growth. This is in line with the findings of Wolde-Rufael and Menyah [12] for Japan, Netherlands and Switzerland ; and Chu and Chang [14] for Japan, the U.K. and the USA. In Bulgaria, Canada, Netherlands, and 
Sweden there is a positive unidirectional causality running from economic growth to nuclear energy consumption showing that increases in economic growth caused increases in nuclear energy consumption, thus energy conservation measures that reduce nuclear energy consumption may not have an adverse effect on economic growth. This finding is similar with the results showed by Yoo and Ku [11] for France and Pakistan ; Wolde-Rufael and Menyah [12] for Canada and Sweden ; and Lee and Chiu [13] for Japan. No causality between nuclear energy consumption and economic growth is found in Argentina, Brazil, France, Pakistan, and the USA, which demonstrates the 'neutrality hypothesis' for nuclear energy consumption. This finding means that energy conservation policies do not affect income, and as such, energy conservation policies may be pursued without adversely affecting real income [42, 43]. In contrast, in Finland, Hungary, India, Japan, Switzerland, and the U.K. there is a positive bidirectional causality between nuclear energy consumption and economic growth. The presence of bidirectional causality between nuclear energy and economic growth lends support for the 'feedback hypothesis' whereby nuclear energy consumption and economic growth are interdependent. This interdependency suggests that energy policies aimed at increasing the production and the consumption of nuclear energy will have a positive impact on economic growth. This in line with the results showed by Yoo and $\mathrm{Ku}$ [11] for Switzerland ; and Lee and Chiu [13] for Canada, Germany and the U.K.

We further find a positive unidirectional causality running from renewable energy consumption to economic growth in Hungary, India, Japan, Netherlands, and Sweden. This implies that, in these countries, increases in renewable energy consumption caused increases in economic growth indicating the presence of the 'growth hypothesis'. Moreover, the positive influence of the use of renewable energy on economic growth further enhances the viability of the renewable energy sector which provides additional support for the assertion that renewable energy can serve as an important energy source for these countries. This result is consistent witn the findings of Payne [22] for the USA. In Argentina, Spain, and Switzerland there is a positive unidirectional causality running from economic growth to renewable energy consumption implying that increases in economic growth caused increases in renewable energy consumption, which indicates the presence of the 'conservation hypothesis'. Thus energy conservation measures that reduce renewable energy consumption may not have an adverse effect on economic growth. These results are in line with Sari et al. [18], Menyah and Wolde-Rufael [8] for the USA, and Tugcu et al. [29] for Germany. In contrast, no causality between renewable energy consumption and economic growth is found in Belgium, Bulgaria, Canada, France, Pakistan, and the USA, which demonstrates the 
'neutrality hypothesis' for renewable energy consumption. This means that energy conservation policies do not affect income, and as such, energy conservation policies may be pursued without adversely affecting real income. However, the presence of the 'feedback hypothesis' has been supported in Brazil, Finland, and Switzerland. The presence of bidirectional causality between renewable energy and economic growth lends support for the feedback hypothesis whereby renewable energy consumption and economic growth are interdependent. This interdependency suggests that energy policies aimed at increasing the production and the consumption of renewable energy will have a positive impact on economic growth.

For the panel results, we find that there is a bidirectional causality between nuclear energy consumption and economic growth. This is in line with the long-run causality found by Apergis et al. [15] for a panel of 19 developed and developing countries and in line with the short-run causality found by Apergis and Payne [16] for a panel of 16 developped and newly developing countries. The presence of a bidirectional causality between nuclear energy and economic growth lends support for the 'feedback hypothesis' whereby nuclear energy consumption and economic growth are interdependent. This interdependency suggests that energy policies aimed at increasing the production and the consumption of nuclear energy will have a positive impact on economic growth. However, we also find that there is unidirectional causality running from economic growth to renewable energy consumption. This is consistent with the finding of Sadorsky [26] for 18 emerging countries. The existence of the unidirectional causality running from economic growth to renewable energy consumption indicates the presence of the 'conservation hypothesis'. Thus energy conservation measures that reduce renewable energy consumption may not have an adverse effect on economic growth.

\section{Conclusion and Policy implications}

While the literature on the two-way linkages between energy type variables and economic growth has increased over the last few years, there is no study that examines this interaction via the simultaneous-equations models. The objective of the present study is to fill this research gap by examining the causality direction between nuclear (renewable) energy consumption and economic growth using dynamic simultaneous-equation panel data models for 17 developed and developing countries over the period 1990-2011. We were motivated by the fact that there are no studies has investigated the two-way linkages between 'nuclear energy 
and economic growth' and 'renewable energy and economic growth' using two structural equations that allow one to simultaneously examine the impact of (i) nuclear (renewable) energy consumption and others variables on economic; and (ii) economic growth and other variables on each energy variables.

Our results for individually and for collectively countries can be summarized as follows. First, according to the causal relationships between nuclear energy consumption and economic growth for individual countries, our results supported evidence of the 'growth hypothesis' for Belgium and Spain; the 'conservation hypothesis' is present for Bulgaria, Canada, Netherlands, and Sweden; the 'neutrality hypothesis' is supported for Finland, Hungary, India Japan, Switzerland, and the U.K.; and the 'feedback hypothesis' is supported for Argentina, Brazil, France, Pakistan, and the USA. Our findings also supported, according to the causal link between renewable energy consumption end economic growth for individual countries, evidence of the 'growth hypothesis' for Hungary, India, Japan, Netherlands, and Sweden ; the 'onservation hypothesis' is supported for Argentina, Spain, and Switzerland ; the 'neutrality hypothesis' is present for Brazil, Finland, and Switzerland ; and the 'feedback hypothesis' is supported for Belgium, Bulgaria, Canada, France, Pakistan, and the USA. Second, for the panel results, we find the existence of a bidirectional causality between nuclear energy consumption and economic growth implying the presence of the 'feedback hypothesis'. We also find the existence of the unidirectional causality running from economic growth to renewable energy consumption, which indicates the presence of the 'conservation hypothesis'.

Our empirical findings have major policy implications as follows. First, the panel results showed that there is bidirectional causality between nuclear energy consumption and economic growth. This interdependence suggests that energy policies designed to increase the production and consumption of nuclear energy will have a positive effect on economic growth. In addistion, given the reduction in the emission of air pollution and greenhouse gases associated with nuclear energy, there is also a positive spillover to the environment. Similarly, the positive influence on economic growth from the use of nuclear energy further enhances the viability of the nuclear energy sector over time. In order not to adversely affect economic growth, efforts must be made to encourage government and industry to increase nuclear energy supply investment and to overcome the constraints on nuclear energy consumption.

Second, we find that a unidirectional causality running from real income to nuclear energy consumption exists for the panel of countries. This implies that economic policies that speed economic growth and development will lead to increases in renewable energy 
consumption, i.e. high economic growth leads to a more environmental degradation, which increases the use of renewable energy. Accordingly, government policies that can increase economic growth and wealth generation should include good monetary and fiscal policies, an economic landscape free of corruption, well functioning labour markets, and policies that focus on increasing innovation and productivity.

\section{References}

[1] Solow, R. M., 1956. A contribution to the theory of economic growth. The quarterly journal of economics 70, 65-94.

[2] Allen, R.C., 2009. The British industrial revolution in global perspective. Cambridge University Press Cambridge. Apergis and Payne, 2009.

[3] Wrigley, E. A. (1990). Continuity, chance and change: The character of the industrial revolution in England. Cambridge University Press.

[4] Hall, C., Tharakan, P., Hallock, J., Cleveland, C., Jefferson, M., 2003. Hydrocarbons and the evolution of human culture. Nature 426, 318-322.

[5] Squalli, J., 2007. Electricity consumption and economic growth: bounds and causality analyses of OPEC countries. Energy Economics 29, 1192-1205.

[6] Ozturk, I., 2010. A literature survey on energy-growth nexus. Energy Policy 38, 340-349.

[7] Yoo, S.H., Jung, K.O., 2005. Nuclear energy consumption and economic growth in korea. Progress in Nuclear Energy 46, 101-109.

[8] Menyah, K., Wolde-Rufael, Y., 2010. CO2 emissions, nuclear energy, renewable energy and economic growth in the US. Energy Policy 38, 2911-2915.

[9] Payne, J. and J. Taylor (2010). Nuclear energy consumption and economic growth in the US: an empirical note. Energy Sources, Part B: Economics, Planning, and Policy 5, 301-307.

[10] Wolde-Rufael, Y., 2010. Bounds test approach to cointegration and causality between nuclear energy consumption and economic growth in India. Energy Policy 38, 52-58.

[11] Yoo, S.H., Ku, S.J., 2009. Causal relationship between nuclear energy consumption and economic growth: A multi-country analysis. Energy policy 37, 1905-1913.

[12] Wolde-Rufael, Y., Menyah, K., 2010. Nuclear energy consumption and economic growth in nine developed countries. Energy Economics 32, 550-556.

[13] Lee, C., Y Chiu, Y., 2011a. Nuclear energy consumption, oil prices, and economic growth: Evidence from highly industrialized countries. Energy Economics 33, 236-248.

[14] Chu, H.P., Chang, T., 2012. Nuclear energy consumption, oil consumption and economic growth in G-6 countries: Bootstrap panel causality test. Energy Policy 48, 762-769.

[15] Apergis, N., Payne, J.E., Menyah, K., Wolde-Rufael, Y., 2010. On the causal dynamics between emissions, nuclear energy, renewable energy, and economic growth. Ecological Economics 69, 2255-2260.

[16] Apergis, N., Payne, J.E., 2010a. A panel study of nuclear energy consumption and economic growth. Energy Economics 32, 545-549.

[17] Nazlioglu, S., Lebe, F., Kayhan, S., 2011. Nuclear energy consumption and economic growthin OECD countries: cross sectionally dependent heterogeneous panel causality analysis. Energy Policy 39, 6615-21.

[18] Sari, R., Ewing, B.T., Soytas, U., 2008. The relationship between disaggregate energy consumption and industrial production in the United States: an ARDL approach. Energy Economics 30, 2302-2313.

[19] Payne, J.E., 2009. On the dynamics of energy consumption and output in the us. Applied Energy 86 (4), 575-577.

[20] Apergis, N., Payne, J.E., 2011. The renewable energy consumption-growth nexus in Central America. Applied Energy 88, 343-347.

[21] Menegaki, AN., 2011. Growth and renewable energy in Europe: A random effect model with evidence for neutrality hypothesis, Energy Economics 33, 257-263.

[22] Payne, J.E., 2011. On biomass energy consumption and real Output in the U.S. Energy Sources Part B: Economics. Planning and Policy 6, 47-52.

[23] Apergis, N., Payne, J.E., 2012. Renewable and non-renewable energy consumption-growth nexus: Evidence from a panel error correction model. Energy Economics 34, 733-738. 
[24] Salim, R.A., Rafiq, S., 2012. Why do some emerging economies proactively accelerate the adoption of renewable energy? Energy Economics 34,1051-1057.

[25] Pao, H.T., Fu, H.C., 2013. Renewable energy, non-renewable energy and economic growth in Brazil. Renewable and Sustainable Energy Reviews 25, 381-392.

[26] Sadorsky, P., 2009. Renewable energy consumption and income in emerging economies. Energy Policy 37, 4021-4028.

[27] Apergis, N, Payne J.E., 2010b. Renewable energy consumption and growth in Eurasia. Energy Economics 32,1392-1397.

[28] Lee, C. Chiu, Y., 2011b. Oil prices, nuclear energy consumption, and economic growth: New evidence using a heterogeneous panel analysis. Energy Policy 39, 2111-2120.

[29] Tugcu, C.T., Ozturk, I., Aslan, A., 2012. Renewable and non-renewable energy consumption and economic growth relationship revisited: evidence from G7 countries. Energy Economics 34, 1942-1950.

[30] Yildirim, E., Sarac, S., Aslan, A., 2012. Energy consumption and economic growth in the USA: Evidence from renewable energy. Renewable and Sustainable Energy Reviews 16, 6770-4.

[31] Apergis, N., Payne, J.E., 2010c. Renewable energy consumption and economic growth: Evidence from a panel of OECD countries. Energy Policy 38, 656-660.

[32] Marques, A.C., Fuinhas, J.A., 2012. Is renewable energy effective in promoting growth? Energy Policy 46, 434-442.

[33] Omri, A., 2013. CO2 emissions, energy consumption and economic growth nexus in MENA countries: evidence froms imultaneous equations models. EnergyEconomics 40, 657-664.

[34] Omri, A., Kahouli, B., 2014a. The nexus between foreign investment, domestic capital and economic growth: empirical evidence from the MENA region. Research in Economics (in press), http://dx.doi.org/10.1016/j.rie.2013.11.001.

[35] Omri, A., Kahouli, B., 2014b. Causal relationships between energy consumption, foreign direct investment and economic growth: Fresh evidence from dynamic simultaneous-equations models. Energy Policy (in press), http://dx.doi.org/10.1016/j.enpol.2013.11.067.

[36] European Union, Commission of the European Communities, 2006. A European Strategy for Sustainable, Competitive and Secure Energy. http://ec.europa.eu/energy/greenpaper-energy/doc/2006_03_08_gp_document_en.pdf2006.

[37] International Energy Agency, 2009. World Energy Outlook, 2009, Paris, France.

[38] BP, 2013. Statistical Review of World Energy. http://www.BP.com 2013.

[39] Dickey, D.A., Fuller, W.A., 1979. Distribution of the estimators for autoregressive time series with a unit root. Journal of the American Statistical Society 75, 427-431.

[40] Phillips, P.C.B., Perron, P., 1988. Testing for a unit root in time series regression. Biometrika 752, 335346.

[41] Vaillancourt, K., Labriet, M., Loulou, R., Waaub, J., 2008. The role of nuclear energy in long-term climate scenarios: an analysis with the World-TIMES model. Energy Policy 36, 2086-2097.

[42] Yang, H.Y., 2000. A note on the causal relationship between energy and GDP in Taiwan. Energy Economics 22, 309-317.

[43] Lee, C.C., 2005. Energy consumption and GDP in developing countries: a cointegrated panel analysis. Energy Economics 27, 415-427. 


\section{Table 1}

Summary of empirical studies on the causality between nuclear (renewable) energy consumption and evonomic growth.

\begin{tabular}{|c|c|c|c|c|c|}
\hline No. & Author(s) & Counry(ies) & Period & Methodology & Confirmed hypothesis \\
\hline \multicolumn{6}{|c|}{ First nexus : Nuclear consumption-Growth } \\
\hline \multicolumn{6}{|c|}{ A-Time series studies } \\
\hline 1. & Yoo and Jung [7] & Korea & $1972-2002$ & VECM & Growth hypothesis \\
\hline 2. & Yoo and $\mathrm{Ku}[11]$ & Six countries & $1965-2005$ & $\begin{array}{l}\text { Hsiao’s version of } \\
\text { Granger causality, } \\
\text { Granger causality, } \\
\text { ECM, cointegration }\end{array}$ & $\begin{array}{l}\text { Growth hypothesis : Korea } \\
\text { Conservation hypothesis : France, Pakistan } \\
\text { Feedback hypothesis : Switzerland } \\
\text { Neutrality hypothesis : Argentina, Germany }\end{array}$ \\
\hline 3. & Payne and Taylor [9] & USA & $1957-2006$ & TY approach & Neutrality hypothesis \\
\hline 4. & $\begin{array}{l}\text { Menyah and Wolde- } \\
\text { Rufael [8] }\end{array}$ & USA & $1960-2007$ & TY approach & Neutrality hypothesis \\
\hline 5. & Wolde-Rufael [10] & India & 1969-2006 & TY approach & Neutrality hypothesis \\
\hline 6. & $\begin{array}{l}\text { Wolde-Rufael and } \\
\text { Menyah [12] }\end{array}$ & $\begin{array}{l}\text { Nine developed } \\
\text { countries }\end{array}$ & 1971-2005 & TY approach & $\begin{array}{l}\text { Growth hypothesis : Japan, Netherlands, } \\
\text { Switzerland } \\
\text { Conservation hypothesis : Canada, Sweden } \\
\text { Feedback hypothesis : France, Spain, U.K., } \\
\text { USA. }\end{array}$ \\
\hline 7. & Lee and Chiu [13] & $\begin{array}{l}6 \text { highly } \\
\text { industrialized } \\
\text { countries }\end{array}$ & $1965-2008$ & TY approach & $\begin{array}{l}\text { Conservation hypothesis : Japan } \\
\text { Feedback hypothesis : Canada, Germany, } \\
\text { U.K. } \\
\text { Neutrality hypothesis : France, USA }\end{array}$ \\
\hline 8. & Lee and Chiu [28] & $\begin{array}{l}6 \text { developed } \\
\text { countries }\end{array}$ & $1971-2006$ & $\begin{array}{l}\text { Cointegration, Granger } \\
\text { causality }\end{array}$ & $\begin{array}{l}\text { Conservation hypothesis (in the lon run) } \\
\text { Neutrality hypothesis (in the short run) }\end{array}$ \\
\hline 9. & Chu and Chang [14] & G-6 countries & $1971-201$ & Granger causality & $\begin{array}{l}\text { Growth hypothesis : Japan, U.K., USA } \\
\text { Neutrality hypothesis : Canada, France, } \\
\text { Germany }\end{array}$ \\
\hline \multicolumn{6}{|c|}{ B-Panel data studies } \\
\hline 10. & Apergis et al. [15] & $\begin{array}{l}19 \text { developed } \\
\text { and developing } \\
\text { countries }\end{array}$ & $1984-2007$ & Panel VECM & $\begin{array}{l}\text { Feedback hypothesis (in the long run) } \\
\text { Growth hypothesis (in the short run) }\end{array}$ \\
\hline 11. & Apergis and Payne [16] & $\begin{array}{l}16 \text { developped } \\
\text { and newly } \\
\text { developing } \\
\text { countries }\end{array}$ & $1980-2005$ & Panel VECM & $\begin{array}{l}\text { Feedback hypothesis (in the short run) } \\
\text { Growth hypothesis (in the long run) }\end{array}$ \\
\hline 12. & Nazlioglu et al. [17] & $\begin{array}{l}14 \text { OECD } \\
\text { countries }\end{array}$ & $1980-2007$ & $\begin{array}{l}\text { Panel Granger causality, } \\
\text { TY approach }\end{array}$ & Neutrality hypothesis \\
\hline
\end{tabular}

Second nexus : Renewable consumption-Growth

\begin{tabular}{|c|c|c|c|c|c|}
\hline \multicolumn{6}{|c|}{ A-Time series studies } \\
\hline 13. & Sari et al. [18] & USA & 1969-1999 & ARDL approach & Conservation hypothesis \\
\hline 14. & Payne [19] & USA & 1949-2006 & TY approach & Neutrality hypothesis \\
\hline 15. & $\begin{array}{l}\text { Menyah and Wolde- } \\
\text { Rufael [8] }\end{array}$ & USA & $1960-2007$ & Granger causality tests & Conservation hypothesis \\
\hline 17. & Payne [22] & USA & $1949-2007$ & TY approach & Growth hypothesis \\
\hline 18. & Salim and Rafiq [24] & 6 countries & 1980-2006 & Granger causality & $\begin{array}{l}\text { Feedback hypothesis (in the short-run) } \\
\text { Conservation hypothesis (in the long-run) }\end{array}$ \\
\hline 19. & Tugcu et al. [29] & G-7 countries & $1980-2009$ & Hatemi-J causality tests & $\begin{array}{l}\text { Neutrality hypothesis : France, Italy, Canada, } \\
\text { U.S.A } \\
\text { Feedback hypothesis : England and Japan } \\
\text { Conservation hypothesis : Germany }\end{array}$ \\
\hline 19. & Yildirim et al. [30] & USA & $1949-2010$ & $\begin{array}{l}\text { Toda-Yamamoto and } \\
\text { Hatemi-J causality tests }\end{array}$ & $\begin{array}{l}\text { Neutrality hypothesis, } \\
\text { Growth hypothesis (causality from biomass- } \\
\text { waste-derived energy }\end{array}$ \\
\hline 20. & Pao and $\mathrm{Fu}[25]$ & Brazil & $1980-2010$ & ECM & Feedback hypothesis \\
\hline
\end{tabular}




\section{B- Panel data studies}

\begin{tabular}{c|l|l|l|l|l}
\hline 21. & Sadorsky [26] & $\begin{array}{l}18 \text { emerging } \\
\text { countries }\end{array}$ & $1994-2003$ & $\begin{array}{l}\text { Bivariate panel error } \\
\text { correction model }\end{array}$ & Conservation hypothesis \\
\hline 22. & Apergis and Payne [27] & $\begin{array}{l}13 \text { Eurasia } \\
\text { countries }\end{array}$ & $1992-2007$ & $\begin{array}{l}\text { Panel ECM (Granger } \\
\text { causality) }\end{array}$ & Feedback hypothesis \\
\hline 23. & Apergis and Payne [31] & $\begin{array}{l}20 \text { OECD } \\
\text { countries }\end{array}$ & $1985-2005$ & Panel Granger causality & Feedback hypothesis \\
\hline 25. & Apergis and Payne [20] & $\begin{array}{l}\text { 6 Central } \\
\text { American } \\
\text { countries }\end{array}$ & $1980-2006$ & Panel ECM & Feedback hypothesis \\
\hline 26. & Menegaki [21] & $\begin{array}{l}\text { 27 European } \\
\text { countries }\end{array}$ & $1997-2007$ & $\begin{array}{l}\text { Multivariate panel } \\
\text { framework }\end{array}$ & Neutrality hypothesis \\
\hline \multirow{2}{*}{ 27. } & Apergis and Payne [23] & 80 countries & $1990-2007$ & Panel ECM & Feedback hypothesis \\
\hline
\end{tabular}

Notes: VECM refers to the vector error correction model, ECM refers to the error correction model, TY approach refers to Toda-Yamamoto approach to Granger causality, and ARDL refers to the auto regressive distributed lag procedure. 
Table 2

Descriptive statistics of the used variables (before taken logarithm).

\begin{tabular}{|c|c|c|c|c|c|c|c|c|c|}
\hline & $\begin{array}{l}\text { Descriptives } \\
\text { statistics }\end{array}$ & GDP (constant 2005 US) & $\begin{array}{l}\text { Nuclear energy } \\
\text { consumption } \\
\text { (WTh) }\end{array}$ & $\begin{array}{l}\text { Combustible renewables } \\
\text { and waste \% of total energy } \\
\text { (in thousands of metric } \\
\text { tons) }\end{array}$ & $\begin{array}{l}\mathrm{CO}_{2} \text { (in million } \\
\text { tonnes carbon } \\
\text { dioxide) }\end{array}$ & $\begin{array}{l}\text { K (billions of } \\
\text { constant } 2005 \\
\text { US) }\end{array}$ & L (in million) & $\begin{array}{l}\text { OP (spot price on } \\
\text { WTI) }\end{array}$ & $\begin{array}{l}\text { OC (in thousand } \\
\text { barrels daily) }\end{array}$ \\
\hline \multirow[t]{3}{*}{ Argentina } & Means & 275.430 & 7.238 & 2526.397 & 139.044 & 30.153 & 15.898 & 40.156 & 459.534 \\
\hline & Std. dev. & 37.418 & 0.638 & 433.271 & 23.111 & 8.313 & 1.865 & 27.091 & 53.131 \\
\hline & $\mathrm{CV}$ & 0.135 & 0.088 & 0.171 & 0.166 & 0.275 & 0.117 & 0.674 & 0.674 \\
\hline \multirow[t]{3}{*}{ Belgium } & Means & 319.006 & 45.766 & 1439.689 & 150.268 & 69.137 & 4.410 & 40.156 & 627.224 \\
\hline & Std. dev. & 105.865 & 2.579 & 775.107 & 8.253 & 9.888 & 0.304 & 27.091 & 64.440 \\
\hline & CV & 0.331 & 0.056 & 0.538 & 0.054 & 0.143 & 0.068 & 0.674 & 0.102 \\
\hline \multirow[t]{3}{*}{ Brazil } & Means & 808.016 & 7.886 & 57426.360 & 350.314 & 145.460 & 84.667 & 40.156 & 2036.152 \\
\hline & Std. dev. & 160.205 & 5.749 & 12697.560 & 68.259 & 37.255 & 12.076 & 27.091 & 346.885 \\
\hline & $\mathrm{CV}$ & 0.198 & 0.729 & 0.221 & 0.194 & 0.256 & 0.142 & 0.674 & 0.170 \\
\hline \multirow[t]{3}{*}{ Bulgaria } & Means & 25.565 & 16.685 & 508.290 & 50.318 & 5.162 & 3.662 & 40.156 & 94.140 \\
\hline & Std. dev. & 5.192 & 2.367 & 277.415 & 5.404 & 2.805 & 0.211 & 27.091 & 12.659 \\
\hline & $\mathrm{CV}$ & 0.203 & 0.141 & 0.545 & 0.107 & 0.543 & 0.057 & 0.674 & 0.134 \\
\hline \multirow[t]{3}{*}{ Canada } & Means & 984.876 & 85.867 & 10798.03 & 574.614 & 180.291 & 16.630 & 40.156 & 2059.461 \\
\hline & Std. dev. & 176.305 & 10.255 & 1455.273 & 54.967 & 63.630 & 1.569 & 27.091 & 248.232 \\
\hline & $\mathrm{CV}$ & 0.179 & 0.119 & 0.134 & 0.095 & 0.352 & 0.094 & 0.674 & 0.120 \\
\hline \multirow[t]{3}{*}{ Finland } & Means & 170.257 & 21.813 & 6295.586 & 55.285 & 34.301 & 2.607 & 40.156 & 217.848 \\
\hline & Std. dev. & 31.218 & 1.817 & 1323.103 & 4.119 & 8.209 & 0.075 & 27.091 & 7.771 \\
\hline & $\mathrm{CV}$ & 0.183 & 0.083 & 0.210 & 0.074 & 0.239 & 0.028 & 0.674 & 0.035 \\
\hline \multirow[t]{3}{*}{ France } & Means & 1947.706 & 404.277 & 12049.1 & 419.604 & 363.503 & 27.689 & 40.156 & 1924.307 \\
\hline & Std. dev. & 226.116 & 41.575 & 1357.377 & 15.928 & 57.573 & 1.489 & 27.091 & 76.311 \\
\hline & $\mathrm{CV}$ & 0.116 & 0.102 & 0.112 & 0.037 & 0.158 & 0.053 & 0.674 & 0.039 \\
\hline \multirow[t]{3}{*}{ Hungary } & Means & 94.037 & 14.016 & 1008.672 & 61.452 & 19.341 & 4.264 & 40.156 & 154.526 \\
\hline & Std. dev. & 15.088 & 1.044 & 400.537 & 3.961 & 4.543 & 0.133 & 27.091 & 14.688 \\
\hline & CV & 0.160 & 0.074 & 0.397 & 0.064 & 0.234 & 0.031 & 0.674 & 0.095 \\
\hline \multirow[t]{3}{*}{ India } & Means & 694.407 & 14.051 & 150841.8 & 1028.998 & 196.977 & 413.170 & 40.156 & 2231.931 \\
\hline & Std. dev. & 299.116 & 6.812 & 12002.23 & 339.923 & 119.253 & 49.220 & 27.091 & 722.138 \\
\hline & $\mathrm{CV}$ & 0.430 & 0.484 & 0.079 & 0.330 & 0.605 & 0.119 & 0.674 & 0.323 \\
\hline
\end{tabular}




\begin{tabular}{|c|c|c|c|c|c|c|c|c|c|}
\hline Japan & Means & 4332.039 & 273.950 & 5930.258 & 1309.605 & 1056.226 & 66.743 & 40.156 & 5318.858 \\
\hline & Std. dev. & 259.609 & 46.178 & 834.257 & 73.340 & 86.407 & 0.945 & 27.091 & 423.086 \\
\hline & CV & 0.059 & 0.168 & 0.140 & 0.056 & 0.081 & 0.014 & 0.674 & 0.079 \\
\hline \multirow[t]{3}{*}{ Netherlands } & Means & 578.006 & 3.846 & 1992.436 & 248.551 & 112.020 & 8.071 & 40.156 & 896.09 \\
\hline & Std. dev. & 89.018 & 0.369 & 889.084 & 15.902 & 18.599 & 0.718 & 27.091 & 103.146 \\
\hline & $\mathrm{CV}$ & 0.154 & 0.095 & 0.446 & 0.063 & 0.166 & 0.088 & 0.674 & 0.115 \\
\hline \multirow[t]{3}{*}{ Pakistan } & Means & 93.083 & 1.476 & 23891.31 & 116.482 & 18.588 & 44.497 & 40.156 & 334.589 \\
\hline & Std. dev. & 25.141 & 1.120 & 3092.243 & 32.833 & 3.658 & 9.620 & 27.091 & 57.054 \\
\hline & CV & 0.270 & 0.758 & 0.129 & 0.281 & 0.196 & 0.216 & 0.674 & 0.170 \\
\hline \multirow[t]{3}{*}{ Spain } & Means & 973.265 & 58.212 & 4628.394 & 319.967 & 253.238 & 19.032 & 40.156 & 1348.977 \\
\hline & Std. dev. & 181.105 & 3.326 & 1107.651 & 58.832 & 65.907 & 2.704 & 27.091 & 212.439 \\
\hline & CV & 0.186 & 0.057 & 0.239 & 0.183 & 0.260 & 0.142 & 0.674 & 0.157 \\
\hline \multirow[t]{3}{*}{ Sweden } & Means & 326.473 & 67.484 & 8161.86 & 60.879 & 57.741 & 4.666 & 40.156 & 346.505 \\
\hline & Std. dev. & 55.311 & 6.328 & 1694.537 & 3.107 & 12.931 & 0.184 & 27.091 & 19.433 \\
\hline & $\mathrm{CV}$ & 0.169 & 0.093 & 0.207 & 0.051 & 0.223 & 0.039 & 0.674 & 0.056 \\
\hline \multirow[t]{3}{*}{ Switzerland } & Means & 364.507 & 25.691 & 1855.703 & 44.055 & 78.329 & 4.098 & 40.156 & 262.193 \\
\hline & Std. dev. & 39.769 & 1.629 & 286.240 & 1.496 & 8.365 & 0.229 & 27.091 & 12.520 \\
\hline & CV & 0.109 & 0.063 & 0.154 & 0.033 & 0.106 & 0.055 & 0.674 & 0.047 \\
\hline \multirow[t]{3}{*}{ United Kingdom } & Means & 1984.494 & 80.536 & 2762.021 & 574.614 & 320.955 & 29.920 & 40.156 & 1724.845 \\
\hline & Std. dev. & 341.552 & 13.056 & 17.15.196 & 54.967 & 67.683 & 1.146 & 27.091 & 70.110 \\
\hline & $\mathrm{CV}$ & 0.172 & 0.162 & 0.620 & 0.095 & 0.210 & 0.038 & 0.674 & 0.040 \\
\hline \multirow[t]{3}{*}{ United States } & Means & 10861.61 & 759.357 & 73616.99 & 6065.197 & 1892.791 & 145.638 & 40.156 & 18962.22 \\
\hline & Std. dev. & 1893.305 & 83.170 & 7805.871 & 351.796 & 453.214 & 10.284 & 27.091 & 1294.318 \\
\hline & $\mathrm{CV}$ & 0.174 & 0.109 & 0.106 & 0.058 & 0.239 & 0.070 & 0.674 & 0.068 \\
\hline \multirow[t]{3}{*}{ Panel } & Means & 1475.984 & 111.068 & 21507.32 & 680.544 & 287.810 & 52.687 & 40.156 & 2294.083 \\
\hline & Std. dev. & 2628.871 & 194.581 & 38447.4 & 1397.876 & 486.835 & 98.263 & 27.091 & 4375.259 \\
\hline & CV & 1.781 & 1.751 & 1.787 & 2.054 & 1.691 & 1.865 & 0.674 & 1.907 \\
\hline
\end{tabular}
consumption. 
Table 3

Simultaneous equations GMM estimation for Eqs.6.

\begin{tabular}{|c|c|c|c|c|c|c|c|c|c|c|}
\hline \multirow[b]{3}{*}{ Independent variables } & \multicolumn{9}{|c|}{ Dependent variable : Economic growth (Y) } & \\
\hline & \multicolumn{5}{|c|}{ Model 1} & \multirow[b]{2}{*}{ Intercept } & \multicolumn{4}{|c|}{ Model 2} \\
\hline & Intercept & $\mathrm{Y}(-1)$ & NEC & $\mathrm{K}$ & $\mathrm{L}$ & & $\mathrm{Y}(-1)$ & REC & $\mathrm{K}$ & $\bar{L}$ \\
\hline Argentina & $2.973 * \quad(0.000)$ & - & $(0.107)$ & $0.116^{* * *}(0.000)$ & $\begin{array}{ll}0.647 * & (0.005)\end{array}$ & $2.621^{*} \quad(0.001)$ & - & $0.157 \quad(0.122)$ & $0.096 \quad(0.127)$ & $0.533^{*}(0.000)$ \\
\hline Belgium & $4.531^{* *} \quad(0.011)$ & - & $0.199 * * *(0.087)$ & $(0.345)$ & $-0.134 * * *(0.091)$ & $2.651^{* * *}(0.057)$ & - & $0.148 \quad(0.111)$ & $0.291 \quad(0.160)$ & $-0.117 * *(0.046)$ \\
\hline Brazil & $-1.818^{*} \quad(0.000)$ & - & $(0.109)$ & $(0.117)$ & $(0.000)$ & $-1.329 * * *(0.064)$ & - & $0.171^{*} \quad(0.000)$ & $-0.270^{* *}(0.031)$ & $-0.277^{*}(0.003)$ \\
\hline Bulgaria & $0.879 * * \quad(0.055)$ & - & $(0.563)$ & $0.357^{*} \quad(0.000)$ & $(0.746)$ & $0.612 * * \quad(0.025)$ & - & $0.062 \quad(0.140)$ & $0.334^{*} \quad(0.000)$ & $0.264 \quad(0.147)$ \\
\hline Canada & $0.766^{*} \quad(0.000)$ & - & $(0.130)$ & $(0.126)$ & $(0.119)$ & 0.894* $\quad(0.001)$ & - & $0.086 \quad(0.107)$ & $-0.081 \quad(0.273)$ & $0.098^{* * *}(0.061)$ \\
\hline Finland & $-0.524 * * *(0.094)$ & - & $0.173^{* *} \quad(0.019)$ & $0.205^{* *} \quad(0.011)$ & $0.277^{*} \quad(0.007)$ & $\begin{array}{ll}-.508 * * \quad(0.019)\end{array}$ & - & $0.195 * * *(0.093)$ & $0.097 * * \quad(0.043)$ & $0.146 * * \quad(0.022)$ \\
\hline France & $1.379 * \quad(0.000)$ & - & $0.111 \quad(0.121)$ & $0.307 * \quad(0.001)$ & $0.199 * * *(0.056)$ & $2.304 * * * \quad(0.000)$ & - & $0.087 \quad(0.174)$ & $0.226 * * \quad(0.029)$ & $0.178 \quad(0.101)$ \\
\hline Hungary & $0.492 * * \quad(0.035)$ & - & $0.192 * * \quad(0.035)$ & $0.668^{*} \quad(0.000)$ & $0.307^{*} \quad(0.000)$ & $0.677 * * \quad(0.020)$ & - & $0.192 * *(0.021)$ & $0.554 * * *(0.000)$ & $0.316 * \quad(0.002)$ \\
\hline India & $1.321^{*} \quad(0.000)$ & - & $0.175^{* *} \quad(0.011)$ & $-0.087 \quad(0.231)$ & $(0.140)$ & $1.298^{*} \quad(0.000)$ & - & $0.786^{*} \quad(0.000)$ & $0.022 \quad(0.456)$ & $-0.073 \quad(0.743)$ \\
\hline Japan & $6.982^{* *} \quad(0.036)$ & - & $0.220^{* * *}(0.055)$ & $0.233^{*} \quad(0.000)$ & $(0.155)$ & $2.043^{* *} \quad(0.042)$ & - & $0.366^{*} \quad(0.005)$ & $0.189 * * \quad(0.021)$ & $0.095 \quad(0.238)$ \\
\hline Netherlands & $-2.542 * * \quad(0.019)$ & - & $(0.046)$ & $0.157^{* * *}(0.067)$ & $0.277^{*} \quad(0.000)$ & $-2.716^{*} \quad(0.009)$ & - & $0.133 * * *(0.077)$ & $0.158 \quad(0.164)$ & $0.199 * * \quad(0.034)$ \\
\hline Pakistan & $-0.268^{* *} \quad(0.029)$ & - & $(0.358)$ & $0.201^{*} \quad(0.000)$ & $0.166^{* * *}(0.092)$ & $-0.561 * \quad(0.003)$ & - & $0.281 \quad(0.201)$ & $0.231^{* * *}(0.058)$ & $0.151 \quad(0.119)$ \\
\hline Spain & $1.704^{*} \quad(0.000)$ & - & $0.245^{*} \quad(0.000)$ & $0.242^{* * *}(0.055)$ & $-0.092 * * \quad(0.043)$ & $1.599 * * \quad(0.023)$ & - & $0.064 \quad(0.412)$ & $0.211 \quad(0.101)$ & $-0.113^{* *}(0.031)$ \\
\hline Sweden & $4.291 * \quad(0.005)$ & - & $(0.196)$ & $0.783^{*} \quad(0.000)$ & $(0.196)$ & $4.311^{*} \quad(0.000)$ & - & $0.369 * \quad(0.000)$ & $0.804 * \quad(0.000)$ & $-0.181 \quad(0.206)$ \\
\hline Switzerland & $2.215^{*} \quad(0.000)$ & - & $0.174^{* * *}(0.090)$ & $0.428^{*} \quad(0.000)$ & $(0.180)$ & $1.994 * * \quad(0.012)$ & - & $0.155 \quad(0.134)$ & $0.399 * * \quad(0.049)$ & $0.142 \quad(0.121)$ \\
\hline U.K. & $-4.447 * * \quad(0.022)$ & - & $0.429 * \quad(0.000)$ & $0.205^{* * *}(0.081)$ & $0.178^{* * *}(0.073)$ & $-4.002 * \quad(0.009)$ & - & $0.199 * * *(0.012)$ & $0.191 \quad(0.102)$ & $0.209 * * \quad(0.041)$ \\
\hline USA & $-2.245^{*} \quad(0.000)$ & - & $(0.203)$ & $0.199 * * \quad(0.013)$ & $0.306^{*} \quad(0.000)$ & $-2.252 * \quad(0.000)$ & - & $0.034 \quad(0.645)$ & $0.176 * * *(0.051)$ & $0.292 *(0.003)$ \\
\hline Panel & $1.833^{*}(0.000)$ & $0.175^{* * * *}(0.082)$ & $0.177^{* *}(0.022)$ & $0.393 *(0.004)$ & $0.039(0.431)$ & $1.889 * \cdot(0.000)$ & $0.223 * * \quad(0.021)$ & $0.012 \quad(0.403)$ & $0.194 * * \quad(0.019)$ & $0.054(0.166)$ \\
\hline Hansen test (P-value) & & & 25.4 & $(0.192)$ & & & & 20.1 & $(0.409)$ & \\
\hline DWH test (p-value) & & & 4.4 & $(0.031)$ & & & & 5.00 & $(0.025)$ & \\
\hline
\end{tabular}

Notes: Values in parenthesis are the estimated p-values. Hansen J-test refers to the over-identification test for the restrictions in GMM estimation. DWH-test is the Durbin-Wu-Hausman test for endogeneity. ${ }^{*},{ }^{* * *}$, and ${ }^{* * *}$ indicate significance at the $1 \%, 5 \%$, and $10 \%$ levels, respectively. 
Table 4

Simultaneous equations GMM estimation for Eqs. 7.

\begin{tabular}{|c|c|c|c|c|c|c|c|c|c|c|c|c|c|c|}
\hline \multirow{3}{*}{$\begin{array}{l}\text { Independent variables } \\
\text { Argentina }\end{array}$} & \multicolumn{6}{|c|}{ Nuclear energy consumption (model 1) } & \multicolumn{8}{|c|}{ Renewable energy consumption (model 2) } \\
\hline & Intercept & \multirow[t]{2}{*}{ NEC (-1) } & $\bar{Y}$ & $\mathrm{CO}_{2}$ & $\mathrm{OP}$ & \multirow{2}{*}{$\frac{\mathrm{OC}}{-0.172 * * *(0.053)}$} & Intercept & REC (-1) & \multicolumn{2}{|c|}{$\mathrm{Y}$} & $\mathrm{CO}_{2}$ & \multicolumn{2}{|c|}{$\mathrm{OP}$} & OC \\
\hline & $-2.624 *(0.002)$ & & $0.067 \quad(0.785)$ & $0.145 \quad(0.109)$ & $0.022 \quad(0.271)$ & & $15.771^{*} \quad(0.000)$ & 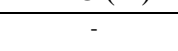 & $0.194^{* *}$ & $(0.048)$ & $0.159 * * \quad(0.023)$ & $0.241^{* * *}$ & $(0.088)$ & $\begin{array}{ll}-0.093 & (0.087)\end{array}$ \\
\hline Belgium & $1.691^{* * *}(0.090)$ & - & $0.137 \quad(0.107)$ & $0.153 \quad(0.483)$ & $0.160 * * *(0.066)$ & $\begin{array}{ll}-0.339 & (0.135)\end{array}$ & $3.792 * * \quad(0.032)$ & - & 0.158 & $(0.211)$ & $0.168 * * * \quad(0.071)$ & $0.394 *$ & $(0.000)$ & $-0.167 \quad(0.137)$ \\
\hline Brazil & $6.998^{*} \quad(0.000)$ & - & $0,377 \quad(0.127)$ & $0.426^{*} \quad(0.000)$ & $0.183^{* * *}(0.061)$ & $-0.192 * *(0.000)$ & $2.686^{* *} \quad(0.020)$ & - & $0.165 *$ & $(0.000)$ & $0.205 * * \quad(0.048)$ & 0.077 & $(0.256)$ & $-0.180 * *(0.044)$ \\
\hline Bulgaria & $5.031^{*} \quad(0.002)$ & - & $0.175^{* *}(0.021)$ & $0.097 \quad(0.199)$ & $0.118^{* *}(0.046)$ & $-0.056 \quad(0.531)$ & $15.667 * \quad(0.000)$ & - & 0.176 & $(0.011)$ & $(0.102)$ & 0.133 & $(0.113)$ & $-0.209^{*} \quad(0.000)$ \\
\hline Canada & $8.818^{*} \quad(0.009)$ & - & $0.186^{*} \quad(0.000)$ & $0.129^{* * *}(0.011)$ & $0.103 \quad(0.244)$ & $-0.009 \quad(0.502)$ & $1.847^{* *} \quad(0.031)$ & - & 0,082 & $(0.199)$ & $0.185^{* * *} \quad(0.057)$ & $0.381^{*}$ & $(0.001)$ & $\begin{array}{ll}-0.083 & (0.377)\end{array}$ \\
\hline Finland & $-1.830 * *(0.046)$ & - & $0.155^{* *} \quad(0.018)$ & $0.142 * * *(0.056)$ & $0.193^{* *}(0.022)$ & $-0.076 \quad(0.244)$ & $(0.000)$ & - & $0.206^{* *}$ & $(0.017)$ & $(0.188)$ & $0.219^{* *}$ & $(0.010)$ & $-0.166 \quad(0.101)$ \\
\hline France & $-3.289 * *(0.015)$ & - & $0,066 \quad(0.355)$ & $0.133 \quad(0.122)$ & $0.411^{*}(0.007)$ & $-0.213 \quad(0.100)$ & $21.969 * \quad(0.000)$ & - & 0,088 & $(0.215)$ & $0.277 * * \quad(0.043)$ & 0.077 & $(0.121)$ & $-0.191 * * *(0.092)$ \\
\hline Hungary & $5.389 * \quad(0.000)$ & - & $0.389 * *(0.045)$ & $0.105 \quad(0.155)$ & $0.043 \quad(0.355)$ & $-0.134^{* * *}(0.002)$ & $12.697 * * \quad(0.011)$ & - & 0.081 & $(0.171)$ & $(0.113)$ & $0.200 * *$ & $(0.013)$ & $-0.092 \quad(0.263)$ \\
\hline India & $-5.662 * *(0.028)$ & - & $0.569 * \quad(0.000)$ & $0.164 * *(0.021)$ & $0.102 \quad(0.122)$ & $\begin{array}{ll}-0.099 & (0.107)\end{array}$ & $10.699 * \quad(0.000)$ & - & 0.156 & $(0.123)$ & $(0.218)$ & $0.178^{* * *}$ & $(0.066)$ & $-0.117 \quad(0.144)$ \\
\hline Japan & $12.278^{*}(0.003)$ & - & $0.269^{* *}(0.049)$ & $0.126 \quad(0.118)$ & $0.077 \quad(0.189)$ & $-0.241^{* * *}(0.078)$ & $-7.043^{* * *}(0.065)$ & - & 0.138 & $(0.108)$ & $0.216^{* *} \quad(0.037)$ & 0.021 & $(0.417)$ & $-0.182^{* * *}(0.059)$ \\
\hline Netherlands & $0.955^{* * *}(0.057)$ & - & $0.161^{* * *}(0.044)$ & $0.092 \quad(0.208)$ & $0.188^{* *}(0.033)$ & $\begin{array}{ll}-0.087 & (0.0199)\end{array}$ & $-5.924 * \quad(0.004)$ & - & 0.119 & $(0.143)$ & $(0.269)$ & 0.155 & $(0.105)$ & $-0.090 \quad(0.301)$ \\
\hline Pakistan & $5.118^{*} \quad(0.007)$ & - & $0.189 \quad(0.137)$ & $0.078 \quad(0.356)$ & $0.209 \quad(0.112)$ & $-0.151^{* *}(0.351)$ & $7.756^{* *} \quad(0.016)$ & - & 0.081 & $(0.155)$ & $(0.170)$ & 0.034 & $(0.501)$ & $-0.211^{* * *}(0.061)$ \\
\hline Spain & $7.756^{*} \quad(0.002)$ & - & $0.065 \quad(0.191)$ & $0.177 * *(0.039)$ & $0.241^{* * *}(0.070)$ & $\begin{array}{ll}-0.087 & (0.361)\end{array}$ & $2.121^{* *} \quad(0.031)$ & - & $0.229 * * *$ & $(0.058)$ & $(0.269)$ & $0.271^{*}$ & $(0.002)$ & $-0.088 \quad(0.178)$ \\
\hline Sweden & $5.045^{* * *}(0.057)$ & - & $0.168^{* * *}(0.089)$ & $0.137 \quad(0.134)$ & $0.215 \quad(0.103)$ & $-0.090 \quad(0.147)$ & $-11.171^{*} \quad(0.004)$ & - & 0.119 & $(0.133)$ & $0.198^{* *} \quad(0.032)$ & 0.074 & $(0.287)$ & $-0.231 * * \quad(0.048)$ \\
\hline Switzerland & $-10.225 *(0.000)$ & - & $0.319^{* *}(0.047)$ & $0.097 * * *(0.092)$ & $0.067 \quad(0.280)$ & $-0.198 * * *(0.051)$ & 4.036* $\quad(0.009)$ & - & $0.322^{*}$ & $(0.000)$ & $(0.144)$ & 0.233 & $(0.110)$ & $-0.012 \quad(0.334)$ \\
\hline U.K. & $-12.335 *(0.000)$ & - & $0.369^{*} \quad(0.000)$ & $0.063 \quad(0.177)$ & $0.344 * *(0.016)$ & $-0.189 \quad(0.108)$ & $-9.449 * * \quad(0.024)$ & - & $0.414^{*}$ & $(0.005)$ & $0.266^{* * *} \quad(0.079)$ & 0.089 & $(0.203)$ & $-0.237^{* *} \quad(0.021)$ \\
\hline USA & $3.745^{* * *}(0.051)$ & - & $0,019 \quad(0.244)$ & $0.160 \quad(0.133)$ & $0.219 \quad(0.174)$ & $-0.288^{*}(0.002)$ & $16.131^{*} \quad(0.000)$ & - & 0,144 & $(0.111)$ & $0.285^{* * *}(0.088)$ & $0.269 * * *$ & $(0.069)$ & -0.055 \\
\hline Panel & $7.439 * \quad(0.000)$ & $0.177(0.128)$ & $0.278^{* *}(0.015)$ & $0.195 * * *(0.071)$ & $0.179 * *(0.044)$ & $-0.097 \quad(0.241)$ & $11.342^{*} \quad(0.000)$ & $0.109 \quad(0.179)$ & $0.227 * *$ & $(0.011)$ & $(0.146)$ & $0.099 * * *$ & $(0.073)$ & $0.194(0.116)$ \\
\hline Hansen test (p-value) & \multicolumn{6}{|c|}{$18.778(0.580)$} & \multicolumn{8}{|c|}{$20.222(0.331)$} \\
\hline DWH test (p-value) & & & 6.674 & $(0.005)$ & & & & & & 5.396 & $(0.016)$ & & & \\
\hline
\end{tabular}

Notes: Values in parenthesis are the estimated p-values. Hansen J-test refers to the over-identification test for the restrictions in GMM estimation. DWH-test is the Durbin-Wu-Hausman test for endogeneity. ${ }^{*}, * *$, and ${ }^{* * *}$ indicate significance at the $1 \%, 5 \%$, and $10 \%$ levels, respectively. 